international friendship. Among the tasks of this division will be to diffuse information and to educate public opinion regarding the causes, nature and effects of war, and the means for its prevention and avoidance; to establish a better understanding of international rights and duties and a more perfect sense of international justice among the inhabitants of civilized nations; to cultivate friendly feelings between the inhabitants of different countries, and to increase the knowledge and understanding of each other of the several nations; to promote a general acceptance of peaceable methods in the settlement of international disputes, and to maintain, promote, and assist such establishments, organizations, associations and agencies as shall be deemed necessary or useful in the accomplishment of the purposes for which the Endowment exists. In other words, this division will make practical application of the teachings and findings of the Divisions of International Law and of Economics and History.

It can hardly be doubted that the men at the hear of these three important divisions of the work of the Endowment, with their immediate associates and colleagues in this and other countries, will speedily come to form a veritable faculty of peace, and that the world will look to them more and more for instruction and for inspiration alike. No such broad and philosophic conception of international relations has ever before been put forward as that which the trustees of the Endowment have formulated and made their own. The conception itself and the admirable plans made for its development and application open a new era in the history of the world.

To such great and nobly conceived tasks as these the trustees of the Carnegie Endowment for International Peace have set their hands. Every true lover of his kind will wish them success in their stupendous undertaking, and will offer them earnest and hearty support toward its accomplishment.

\title{
THE FIFTH ANNUAL MEETING OF THE AMERICAN SOCIETY OF INTER- NATIONAL LAW
}

The American Society of International Law held its fifth annual meeting at the New Willard Hotel, Washington, D. C., April 27-29, 1911, and the program, as outlined in the April number of the AMERICAN JourNaL of INTERNATIONAI LAw, was strictly adhered to. The meeting was in a way supplementary to the proceedings of 1910 . In this meeting, the principles were expounded which, it is believed, control the whole country in extending protection to its citizens or subjects residing in foreign countries, that is to say, the question was considered in its international aspect. At the meeting of 1911 the attempt was made to examine and to formulate those principles which should guide and control foreign countries in their treatment of aliens residing or domiciled within them; that is to say, the subject was treated from the standpoint of constitutional law with reference, however, to the principles of 
international theory and practice, which the good sense of mankind have imposed upon independent states in their treatment of aliens within their jurisdiction. As in 1910, so in 1911, the question was subdivided, so that the various phases of the problem might be adequately treated, yet unity was preserved by restricting the papers and discussions to the general topic. It is hoped that in this way the proceedings of 1910 and of 1911 will have a scientific as well as a practical value and that the reports may be a clear and thoughtful exposition of the practice of nations as well as the views of writers of authority on the question of the rights of aliens and the protection which the home government may properly extend to them.

Thursday evening, April 27th, and the morning and evening sessions of April 28th were devoted exclusively to this general subject. The morning session of Saturday, April 29, was given over to the consideration of the report of the committee on codification which the Society regarded as unfinished business. It is hoped, little by little, to prepare in the form of a code those principles of international law which actually do or should control nations in their peaceful intercourse. The Society, however, believes that very great care and attention should be devoted to preliminary matters before attempting a statement of the principles. Therefore, two topics were treated, namely, the primary sources of international obligations, and the relative value of authorities. The committee on codification, which is continued, will take up the subject and will, it is believed, be in a position to report actual progress in the matter of codification at the next annual meeting.

The Society was received, as usual, by the President of the United States (Friday afternoon, April 28th), and the customary dinner was held on the evening of April 29. The dinner was more elaborate than in past years and was more numercusly attended, there being in all 130 present. The President of the United States honored the Society by his presence, and at the guest table were Mr. Taft, who is honorary president of the Society, Mr. Root, president of the Society, the British Ambassador, the Japanese Ambassador, the Chief Justice of the United States, the Chiel Justice of Canada, Judge George Gray, the Chief Justice of the Court of Commerce Appeals, the Secretary of War, the Honorable David J. Foster, ranking member of the Committee on Foreign Affairs of the House of Representatives, and Senator Henri La Fontaine, of Belgium. The addresses were of a very high order, and although the press was excluded, as is the rule, they were nevertheless 
reported for the Society, and for the firat time appear in the printed proceedings.

At the business meeting held on Saturday morning, April 29th, Monsieur Ernest Nys was elected honorary member for the year 1910, and the following officers of the Society for the year 1911 were elected:

\section{Honorary President,}

Hon. William H. Taft.

$$
\text { President, }
$$

Hon. Elihu Root.

$$
\text { Vice-Presidents, }
$$

Chief Justice White,

Hon. John W. Griggs,

Justice William R. Day,

Hon. William W. Morrow,

F.on. P. C. Knox,

Hon. Richard Olney,

Mr. Andrew Carnegie,

Hon. Joseph H. Choate,

Hon. Horace Porter,

Hon. John W. Foster,

Hon. Oscar S. Straus,

Hon. George Gray,

Hon. Shelby M. Cullom,

Hon. Jacob M. Dickinson,

Hon. James B. Angell.

For members of the Executive Council to serve until 1914:

Hon. Richard Bartholdt, Missouri.

Gen. George B. Davis, District of Columbia.

Prof. Charles Noble Gregory, Iowa.

Hon. A. J. Montague, Virginia.

Rear Admiral Charles H. Stockton, District of Columbia.

Charles B. Warren, Esq., Michigan.

Hon. John Sharp Williams, Mississippi.

Prof. Theodore S. Woolsey, Connecticut.

For member of the Executive Council to serve until 191s, to fill vacancy caused by election of Hon. James B. Angell to vice-presidency:

Prof. William R. Manning, Texas.

At the meeting of the Executive Council the present Executive Committee and its officers, and the Board of Editors of the AMrrican JoURNAL of INTERNational LAW were re-elected for the ensuing year. 